\title{
Hierarkkisesta horisontaaliseen ura-ajatteluun
}

\author{
VESA HUOTARI
}

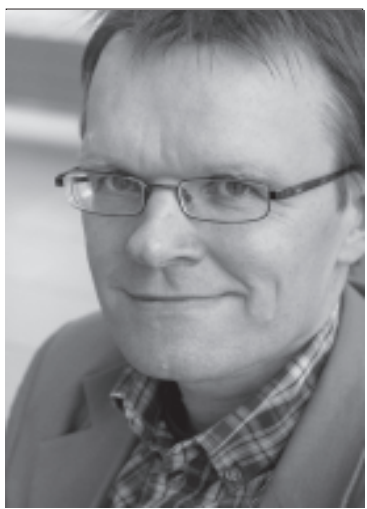

Vanhat termit on toki helppo korvata uusilla. Huomattavasti hankalampaa on löytää horisontaalisuudelle selkeää sisältöä, hahmottaa sille konkreettisia osoittimia ja nostaa se sille paikalle, jota määrittelee hierarkkinen ura-ajattelu. Jälkimmäinen voi olla hankalaa, mutta se voi olla myös välttämätöntä. Jos odotamme urakehitystä perinteisessä uratikapuilla nousun merkityksessä ja jos tällaisia mahdollisuuksia on jatkossa merkittävästi vähemmän kuin aikaisemmin, rakennamme odotuksemme työstä ja työurasta edesmenneelle näkemykselle maailmasta. Yhä elävät kertomukset siitä, miten organisaatioon tullaan lähetiksi ja noustaan sitten peräänantamattomuudella ja lahjakkuudella konsernin pääjohtajaksi, vahvistaisivat tällöin yksinomaan kokemuksia henkilökohtaisesta epäonnistumisesta, riittämättömyydestä ja huonoudesta.

Saamme ajatuksemme, erityisesti tavankaltaiset ajatusmallimme, usein perintöinä. Niiden alkuperä on meille arvoitus. Vasta kun pyrimme ajattelemaan toisin tai laajentamaan ajatteluamme, joudumme omien ajattelutottumustemme tai -perinteiden tosiasian eteen. Mistä oikein juontuu ajatuksemme urasta organisaatiohierarkiassa kohoamisena ja miksi näemme työurat niin kuin ne näemme sekä ajattelemme urakehityksestä niin kuin ajattelemme?
Uskon, että horisontaalisten urakehityksen hahmottamista rasittaa hallitseva ymmärrys aidosta, todellisesta tai oikeasta uralla etenemisestä. Uskon myös, että pyrkimys säilyttää "arvokkain" aikaisemmasta - vertikaalisen muuntaminen horisontaaliseksi tai tulkinta horisontaalisena - on varmin tapa tukahduttaa kaikki se, josta aidosti voisi olla horisontaalisten työurien ominaispiirteeksi tai -luonteeksi. Pystyyn nostettuja tikkaita on helppo kiivetä ylös ja laskeutua alas, mutta kunnolliseksi sillaksi niistä ei yleensä ole.

On ymmärrettävä paremmin alkuperäiseksi tai autenttiseksi tullutta ura-ajattelua. Se on parhaiten korvattavissa systemaattisen perkaamisen, purkamisen ja uudelleen arvioinnin kautta. Artikkelini taustoittaa ura-ajattelua yleensä, ei niinkään osoita tai pyri löytämään sisältöä horisontaaliselle urakehitykselle, määrittele sen luonnetta tai hae sille käypiä osoittimia. Analyysini tähtää enemmänkin analyysiksi kudelman kokoamisena mahdollisista osatekijöistä kuin analyysiksi todellisiksi perusosiksi purkamisena (ks. Strawson 1992). Tavoitteenani on laajentaa kuvaa ura-ajattelusta, työurien muutoksesta ja tähän kytkeytyvän uudenlaisen ajattelun tarpeesta. 


\section{Edistyksen tavoittelu, hierarkia ja meritokratia}

Jo ennen kuin Darwin yleisti evoluution koskemaan eloperäistä luontoa kokonaisuudessaan, jatkuva kehitys on ymmärretty ihmisen osaksi (ks. Nisbet 1979). Jokaisesta, alkujaan suhteellisen kyvyttömästä, tulee suhteellisen kyvykäs yhteisönsä jäsen, joka perii edeltäjiensä työvälineet, heidän raivaamansa maan, asumukset, tietämyksen ja niin edelleen sekä kehittää, laajentaa ja muokkaa niitä edelleen luovuttaakseen ne aikanaan jälkeensä tuleville. Näin edeltäjien työ tulee aina myöhempien hyödyksi ja edistyksestä inhimillistä elämää määrittävä piirre.

Erottamaton osa länsimaista ajattelua on usko siihen, että omalla lahjakkuudella ja kovalla työllä on mahdollista päästä eteenpäin elämässä. Yhteiskunnallinen kehitys on ollut osaltaan erilaisten esteiden poistamista yksilöllisen edistymisen tieltä. Se on tarkoittanut myös tien tasoittamista alkujaan toisia heikommassa asemassa olevien osalta (Daniels 1978). Ideaalina on ollut, että jokainen voisi aloittaa samalta viivalta ja jokainen voisi yltää niin korkealle kuin omat ansiot kantavat (Lister 2006, 232).

Vaihdon ja vastavuoroisuuden periaate löytyy Denchin (2006) mukaan kaikkien sosiaalisten järjestelmien ytimestä ja kaikista kulttuureista: se, mitä yhteiskunnalta voi oikeutetusti vaatia itselleen, on aina yhteydessä siihen, mitä on itse yhteiskunnalle antanut. Jokaiselle on annettava hänen yksilöllisten ansioidensa mukaan, mutta samalla yksikään ei ansaitse mitään yksinomaan syntyperänsä, sukupuolensa, ihonvärinsä, etnisen taustansa tai muun vastaavan perusteella. (Emt., 9) Predestinaatio on näin nähty kaikilla tasoilla, kaikissa muodoissa ja kaikin inhimillisesti mahdollisin, joskin sosiaalisesti - ja ekologisesti - kestävin, keinoin tapahtuvan edistyksen tavoittelun ja jatkuvan eteenpäin menemisen esteeksi.

Kristinusko, jossa jokainen ihminen määrittyi yhdenveroiseksi Jumalan silmissä, saattoi yksinomaan korostaa jokaisen kansalaisen yhdenveroisuutta lain edessä. (De Tocqueville, sit. Béteille 1979, 537.) Taivaaseen kuitenkin liitettiin hierarkia. Enkelien tehtävänä oli toteuttaa Jumalan tahtoa virkamiesten tavoin, käyttää valtaa Jumalan edustajina ja olla toimissaan Hänelle vastuullisia. Enkelit jaettiin kolmeen kategoriaan ja näiden alla yhdeksään luokkaan. Kukin oli sidottu tehtäväänsä ja kyvykäs vain oman kategoriansa puitteissa.
Urakehitys olikin enkelten kohdalla vain rajatusti mahdollista. Se edellytti loistamista kirkkaammin. Kirkkainkaan loistaminen ei auttanut siirtymään omasta kykykategoriasta seuraavaan. Vaikka yleneminen nähtiinkin enkelten maailmassa vain rajatusti mahdolliseksi, tarkoitti se aina pääsyä lähemmäs Jumalaa. Vaikka reformiliikkeet sittemmin hylkäsivätkin ajatuksen taivaallisesta hierarkiasta, siitä ei ollut estämään ajatuksen yhdistämistä kirkon virkahierarkiaan; munkin oli tyydyttävä asemaansa eikä hänen sopinut pyrkiä papiksi, mutta papista saattoi tulla piispa. Vastaavasti keskiajalla oli mahdollista kuulua vain yhteen ammattikiltaan. (Patrides 1959; Mohamed 2004). Vaikka jokaisen työn merkityksen korostamiseen sisältyikin viittaus siitä, että kunkin tuli tyytyä leiviskäänsä, se ei Thruppin (1959) mukaan tarkoittanut, etteikö työntekijä olisi voinut pyrkiä parantamaan omaa asemaansa tarjolla olevien keinojen avulla.

Hierarkkisuuden ideaan sisältyy ajatus eriarvoisuudesta. Yhdenvertaisuuden leimaamat yhteiskunnat (Länsi-Eurooppa nyt, Yhdysvallat) on erotettu hierarkkisuuden leimaamista yhteiskunnista (Eurooppa aikaisemmin, Aasia, erityisesti Intia). Tätä jakoa vastaavasti on konstruoitu kaksi ihmistyyppiä: eriarvoisuutta hyvin kestävä ja muutosta vastustava homo hierarchicus ja demokratiaa tavoitteleva sekä asiantiloja korjaava homo equalis. Kun yhdenvertaisuuden todentumattomuuden oletetaan homo hierarchicuksen kohdalla juontuvan yhteiskunnallisista tekijöistä, haetaan sen syytä homo equaliksen kohdalla satunnaisista tai yksilöllisistä tekijöistä. Katsantokannat yksinkertaistavat Béteillen (1979) mukaan liikaa. Näkökykyä kuitenkin edelleen haittaavat yhtäältä yhdenveroisuuden, yhteiskunnallisen joustavuuden ja sosiaalisen liikkuvuuden ja toisaalta hierarkkisuuden, eriarvoisuuden pysyvyyden ja sosiaalisen liikkumattomuuden ylikorostaminen. Kaikissa sivilisaatioissa on Béteillen mielestä oivallettu molempien merkitys. Olennaista on se, miten yhdenvertaisuus ja hierarkkisuus ymmärretään ja miten niiden milloinkin nähdään liittyvän toisiinsa. Beteillén mukaan pyrkimyksenä on yleensä ollut palkkioiden ja ansioiden saattaminen keskinäiseen tasapainoon. On tunnustettu aina, että oikeudenmukaisuutta rikkoo niin se, että samanarvoisia kohdellaan eriarvoisesti kuin myös se, että eriarvoisia kohdellaan yhdenveroisina. Ajatus ihmisten yhdenvertaisuudesta ei kuitenkaan ole yhdenkään kulttuurin yksinoikeus eikä ole yhteiskuntaa, jossa ei olisi minkäänlaista yksilöiden vä- 
listä erottelua meriittien, laadun tai hyödyn perusteella. (Béteille 1979, 530-536.)

Palkkioiden epätasainen jakautuminen hyväksytään, kun niiden katsotaan menevän tasan suhteessa ansioihin aikaansaannoksina ja saavutuksina. Krauze ja Slomczynski (1985) väittävät, että vahva yhteys yksilöllisten meriittien ja sosiaalisten palkkioiden välillä ilmentää modernin yhteiskunnan pyrkimystä hyödyntää tehokkaasti inhimillisiä resursseja. Siinä määrin kun arvostamme tuottavuutta, kykenemme arvottamaan myös erilaisia ansioita. Meritokraatit katsovat, että eri tehtävät edellyttävät erilaisia inhimillisiä kykyjä ja että eri henkilöillä tällaisia kykyjä on vaihtelevasti. Tällöin tietyt työntekijän ominaisuuksista ja työn vaatimuksista syntyvät yhdistelmät osoittautuvat toisia tuottavammiksi. Juuri meriittien hyödyllisyys tekee niistä arvokkaita, katsoo Daniels (1978).

Yksilölliset meriitit kääntyvät sosiaaliseksi asemaksi, arvostukseksi ja taloudelliseksi tulokseksi organisatoristen ja ammatillisten asemien kautta. Jälkimmäiset eroavat niin hyödyllisyytensä kuin niiden ominaisuuksien osalta, joita niissä menestyminen aseman haltijalta edellyttää. Emme elä yksinomaan organisoidussa yhteiskunnassa vaan organisaatioiden yhdyskunnissa. (Krauze \& Slomczynski 1984).

Sosiaalinen liikkuvuus ja sen myötä kertyvät palkkiot määrittyvät formaalien organisaatioiden puitteissa. Yksittäisen henkilön vaikutus organisaation kokonaissuoritukseen välittyy hänen roolinsa tai osansa kautta. Erinomainen suoriutuminen joissakin positioissa lisää merkittävästi koko organisaation tulosta, mutta huomattavasti vähemmän joissakin toisissa positioissa. Satunnainenkin vakava alisuoriutuminen jossakin suhteellisen matalassa, mutta kokonaisuuden kannalta kriittisessä asemassa voi puolestaan merkittävästi leikata tuloksellisuutta. (Jacobs 1981.) Organisaatioiden puitteissa tapahtuva palkkioiden tavoittelu edellyttää omien, ansioiksi taipuvien ominaisuuksien vahvistamista ja mobilisointia tavalla, joka havaitaan hyödylliseksi. Tarvitaan työmarkkinoita, joilla yksilöllistä osaamista tarjotaan ja ostetaan ja joiden myötä ansioituneimmat voivat sijoittua nuo ansiot hyödyksi ja tuottavuudeksi kääntäviin tehtäviin. (Saunders 2006.)

Meritokraattinen eetos hankaloittaa kaikkien pitämistä ja kohtelemista yhdenveroisina. Kun sosiaalisten palkkioiden ajatellaan jakautuvan meriittien mukaisesti, voivat jaossa vähemmälle jääneet syyttää vain itseään. Jos sata vuotta sitten epä- onnistui sosiaalisessa nousussa, tämän kustannuksia lievensi se, että moni muukin jakoi saman kohtalon. Mitä useamman osaksi sosiaalinen nousu tuli, sitä korkeammiksi kasvoivat tässä epäonnistumisen kustannukset. Samalla kohoaminen itsessään normalisoitui. Yhteiskuntaan, jossa pyritään maksimoimaan sosiaalinen liikkuvuus, jotta jokainen voisi tulla palkituksi ansioittensa antamassa mitassa ja kaikki hyötyisivät maksimaalisesti käytettävissä olevien inhimillisten resurssien täysipainoisesta hyödyntämisestä, kehkeytyy samalla myös sosiaalinen hierarkia, jossa ansioituneimmat löytyvät aina ylemmiltä ja vähemmän ansioituneet alemmilta askelmilta. (Willets 2006; Saunders 2006; Lister 2006.) Meritokratia pyrkii täten varmistamaan yhtäläisen lähtökohdan jokaiselle ja ennustaa eriarvoisuuden luonnehtimaa tulevaisuutta kaikille. (Ks. McCoy \& Major 2006.)

Liikkuvuus on nähty edellytykseksi sille, että yksilön koko kapasiteetti voi maksimaalisesti todentua niin henkilön itsensä kuin hänen yhteisönsäkin hyväksi - Yhdysvaltain armeijan rekrytointiilmoituksen mukaan "Be all that you can be" (Segal \& Segal 1983, 154). Yhteiskunta, joka keinotekoisesti rajoittaa yksittäisten jäsentensä mahdollisuuksia kohentaa omaa asemaansa, leikkaa samalla omia edistymisen mahdollisuuksiaan. ${ }^{1}$ Mitä enemmän korostetaan liikkuvuuden, paremman tavoittelun ja ylöspäin pyrkimisen merkitystä, sitä enemmän kaivetaan samalla maata juuri sen aseman alta, jossa henkilö kulloinkin sattuu olemaan (ks. Fuller 2006, 65) ja tavallinen työ inflatorisoituu (Dench 2006).

Moderni yhteiskunta karttaa tuhlausta ja lahjakkuuksien hukkaamista (Willetsin 2006). Syynä siihen, ettei ei-yksilöllisten ominaisuuksien ja piirteiden käyttämistä sosiaalisen poissulkemisen välineenä nähdä perustelluksi tai oikeutetuksi, ei ole moraalinen edistys vaan se, ettei valikointi, joka tapahtuu ihonvärin, sukupuolen, iän, etnisen taustan tai vastaavan perusteella, ole riittävän tehokasta. Se yksinkertaisesti hukkaa lahjakuutta ja syyllistyy täten tuhlaukseen. (Ks. Fuller 2006).

Koulujärjestelmän tehtävänä onkin varmistaa, ettei lahjakkuuksia joudu hukkaan (Willets 2006). Lahjakkuudet tulisi tunnistaa koulussa ja koulun tulisi kehittää niitä edelleen sekä tehdä yksilölliset erot lahjakkuudessa silmiinpistäviksi todistusten ja arvosanojen avulla. Koulujärjestelmässä jatkokoulutuksen tavoittelijat karsitaan yleensä aikaisemman koulumenestyksen perusteella ja se kokonaisuudessaan siivilöi henkilöitä eri hierarkia- 
tasoille työelämässä. Koulutustason yleisen kohoamisen on aina ymmärretty uhkaavan työelämän alimman portaan töitä. Koulutuksen loppuunsaattamisen yleistyminen on puolestaan vaikeuttanut yrittäjiksi rekrytoitumista. Horowitzin (2006) mielestä meritokratian käsitteen vakavin puute on se, ettei meriittejä kyetä erottamaan koulutuksesta. Meritokratia palkitsee täten hallinnollisista saavutuksista koulujärjestelmässä, ei esimerkiksi älykkyydestä.

\section{Työnjako, organisointi ja uralla eteneminen}

Kokemus on Wrenin (1994) mukaan tehnyt selväksi sen, ettei omin voimin yrittäminen palvele parhaiten omaa etua kaikissa tapauksissa. Hankkiutuminen yhteistyöhön toisten kanssa kannattaa joissakin tilanteissa aina. Yhteistyö tuo resursseja, jotka muuten olisivat vaikeasti saavutettavissa tai jopa kokoaan saavuttamattomissa. Yhdessä tekeminen mahdollistaa työnjaon ja erikoistumisen, mutta luo myös johtamisen, koordinoinnin ja ohjauksen tarpeen. Erikoistuminen puolestaan edelleen eriyttää taitoja ja tekee niiden omaksumisesta hankalampaa sekä enemmän aikaa vaativaa. (Wren 1994.)

Työnjako on jo varhain ymmärretty taloudellisesti merkittäväksi, mutta vasta Adam Smith tulkitsi sitä modernilla tavalla. Smithin mukaan kilpailua tarvittiin sovittamaan yhteen yksilöiden itseintressi ja optimaalinen hyöty. Hänen mielestään kykyerot yksilöiden välillä eivät olleet myötäsyntyisiä vaan pikemminkin tulosta työnjaosta ja taloudellisesta erikoistumisesta. Ajatus työvoiman homogeenisuudesta tarkoitti sitä, että taloudellinen tehokkuus juontui enemmänkin työtä koskevista järjestelyistä työn modernina organisointina kuin työntekijän henkilökohtaisista ominaisuuksista. (McNulty 1973; Wren 1994.) Vaikka työntekijöiden erikoistuminen olikin tuottavuuden kannalta keskeistä, eivät erikoistumisen vaarat jääneet Smithiltä havaitsematta. Yhä useamman kohdalla uhkana oli se, että työ koostui yhden tai kahden yksinkertaisen operaation toistamisesta, ei edellyttänyt tekijältään korkeampien kykyjen käyttöä tai ongelmanratkaisutaitoa eikä näin myöskään kehittänyt niitä. Tällaiset kyvyt olivat täten tuomittuja sammumaan ja työntekijöistä oli tuleva juuri niin tyhmiä, tietämättömiä, karkeita ja kykenemättömiä osallistumaan rationaaliseen keskusteluun tai humaaneihin ja oikeudenmukaisiin arkielämän ratkaisuihin kuin se inhimillisesti vain oli mahdollista. (McNulty 1973.)

Feldin (1959) mukaan hierarkkinen asema ja järki liittyvät kiinteästi toinen toisiinsa. Armeijassa ylempi on aina alempaa paremmin informoitu. Tieto, johon hänellä on pääsy, on olennaisempaa ja kattavampaa, ja alemman on seurattava ylemmän käskyjä siksi, että niissä heijastuu jälkimmäisen parempi tietämys. Käskyt kulkevatkin hierarkiassa ylhäältä alas ja informaatio alhaalta ylös. Ylimmillä, joita on määrällisesti vähän, on kokonaisnäkemys tilanteesta sekä tieto periaatteista, joilla sitä hallitaan ja joiden avulla hyödynnetään menestyksekkäästi sen tarjoamat mahdollisuudet. Alimpina olevilla, joita on määrällisesti paljon ja joiden odotetaan tekevän kuten käsketään, on vain oma henkilökohtainen kokemuksensa taistelusta, muttei tietämystä sen taustalla olevista laskelmista ja periaatteista. (Emt.)

Hallinto oli alkujaan leimallisesti kotitalouden, heimon, sodankäynnin, hovin, valtakunnan ja kirkon hallintoa. Sodankäynti ja armeijoiden tarpeet vaikuttivat merkittävästi talouselämän kehitykseen. Massa-armeijat tarvitsivat suuria määriä standardoituja tuotteita. Teollisuus oppikin sodankäynnistä mm. organisaation, kurinalaisuuden, standardoinnin, huollon, koordinoinnin, linja-esikunta-erottelun sekä työnjaon. (Kaempffert 1941) Vaikka erityisesti armeija on ajateltu hierarkkiseksi, muutosvastaiseksi ja autoritaarisesti johdetuksi organisaatioksi, on se asiallisesti jo pitkään ilmentänyt kaikille byrokraattisille organisaatioille ominaisia piirteitä. Automatiikan tulo on vahvistanut siviilien roolia, sotilasjohto toimii yhä läheisemmässä yhteydessä politiikkaan ja innovaatiotoiminta - ainoa asia, jota teollisuus ei Kaempffertin (1941) mukaan oppinut armeijalta - on yhä merkittävämpää. Janowitzin (1959) mukaan perinteinen sotilasjohtaminen on tehnyt tilaa eksperteille niin teknologiaan kuin organisaation hallintoon sekä ihmissuhteisiin liittyvissä kysymyksissä. Hierarkkinen rakenne koordinaatiovaatimuksineen ja valtakeskittymineen on saanut tehdä tilaa aloitteellisuuden hajauttamiselle sinne, missä vihollinen varsinaisesti kohdataan. Taisteleva sotilas on varsin kaukana Max Weberin sääntöjä seuraavan ideaalibyrokraatin mallista, jopa tämän vastakohta: "He is not detached, routinized, and self-contained; rather his role is one of constant improvisation" (emt., 481).

Autoritaarisesta järjestyksestä siirrytään Janowitzin (1959) mukaan fraternaaliseen - isän kai- 
kenkattavasta vallasta suhteessa lapseen vanhemman lapsen tehtäväkohtaiseen ja rajattuun valtaan suhteessa nuorempaan, yhdenvertaisten tunnustettuun eriarvoisuuteen ("the recognised equality of unequals"). Tämä ei hävitä organisaation formaalia auktoriteettirakennetta. Alemmalla organisaatiotasolla tekniset ja ihmissuhdetaidot sekä lojaalisuus omaa ryhmää kohtaan pätevöittävät osallistumaan tehokkaasti, joskin asiallisesti rajatulta osin, päätöksentekoprosessiin, erityisesti toimeenpanon osalta. Janowitzin mukaan toiminnan perustana on olettamus, että kuka tahansa, joka kykenee osoittamaan oman pätevyytensä, voi edetä urallaan. (Emt.).

Ylentäminen on tapa palkita ja tunnustaa työntekijän aikaansaannokset ja ponnistelut. Sitä ilmentävät usein tehtävä- ja nimikemuutokset sekä palkan, vallan ja vastuun kasvu. Ylentäminen voi tarkoittaa myös vapausasteiden tai riippumattomuuden kasvua tai vaaran ja työaikaan, tilaan tms. liittyvän epämukavuuden vähenemistä. Työntekijät kokevat urakehityksen usein motivoivana ja pyrkivät etenemään urallaan. Tämä lisää sitoutumista organisaatioon ja vähentää vaihtuvuutta. (Go \& Kleiner 2001, 109.) Liikkuvuutta onkin pidetty keskeisenä yksilöllisenä yllykkeenä ja ylentäminen on yksi tärkeimmistä henkilöstöhallinnon mekanismeista (Leonard \& More 2000; Jacobs 1981). Uratikapuut ovat perinteisesti olleet organisaation sisäisiä, hierarkkisia, vakaita, työnantajan kontrolloimia ja yksihuippuisia. Urakehitys on vastaavasti ollut lineaarista ylenemistä. Se on tarkoittanut vastuualueen kasvua esimerkiksi alaisten määränä tai hallinnoitavan budjetin suuruutena (Feldman \& Weitz 1988).

Nykysukupolvi todistaa kuitenkin rajojen sekoittumista elämän eri osa-alueilla. Yksisuuntainen urakehitys on muuttumassa monisuuntaiseksi. (Baruch 2003.) Vaikka 1970-luvulta lähtien huomiota onkin kiinnitetty työuriin ja urakehitykseen, organisaatioaspekti on jäänyt tarkasteluissa lapsipuolen asemaan (Baruch \& Perperl 2000). Organisaatioiden madaltuminen onkin pakottanut kiinnittämään huomiota ylöspäin suuntautuvan uraajattelun kantavuuteen (Ettington 1997). Tämä on synnyttänyt järjestelmällisen urakehityksen suunnittelun (organizational career management) tarpeen. Kysymys on kaikista niistä toimenpiteistä, jotka liittyvät työntekijöiden työuraan. (Baruch \& Peiperl 2000).

Urateoriat lähtivät pitkään selviöstä, että urakehitys tarkoittaa kiipeämistä organisaatiohierar- kiassa (Arthur ym. 2005). Vuonna 1868 säädettiin Englannissa, että virkamiesten ylentämisen tuli tapahtua yksinomaan hankittujen ansioiden, meriittien, perusteella. Jokaisella kuninkaan palvelukseen astuneella tien tuli olla avoin aina ylimpiin asemiin saakka. Tarve avata lahjakkaimmille mahdollisuus edetä urallaan korostui erityisesti sotaaikana. Mitä laajemmalle yhteiskuntaan virkamiesten tehtävät ulottuivat, sitä ilmeisemmäksi kävi sisällöllisen asiantuntemuksen tarve ja välttämättömyys virkatehtävien hoidossa. (Davis 2006.)

Työurien on katsottu muuttuneen nyttemmin monisuuntaisiksi, -muotoisiksi, dynaamisiksi ja rajoiltaan hämärämmiksi. Organisaation, ammatin tai tehtävän sijaan ihmisten on nähty sitoutuvan enemmän itseensä, omaan persoonalliseen kasvuunsa ja oman osaamisensa rikastamiseen ja kehittämiseen. Yksittäisten henkilöiden katsotaankin seuraavan sisäistä karttaa, joka pohjautuu heidän käsitykseensä siitä, mikä uran tulisi olla (Elsass \& Ralston 1989). Urakehitystä tarkastellaan enenevässä määrin henkilön omasta näkökulmasta ja korostetaan ulkoisia työmarkkinoiden, ammatillisen kehittymisen, persoonallisen kehittymisen ja esimerkiksi oman työn ja muun elämän yhteensovittamisen asemaa uran aspekteina. Yleneminen organisaatiohierarkiassa on tässä laajemmassa näkökulmassa vain yksi urakehityksen suunta, ei sen ainoa muoto. Monissa töissä, jotka eivät ole tarjonneet selkeitä ura-askelmia, edistymisen osoittimia on haettu juuri subjektiivisista, tilanne- ja ammattikohtaisista tekijöistä. Eri henkilöt arvostavat usein - osin mahdollisesti olosuhteiden pakosta - eri asioita työssä (palkka, asemapaikka, status, turvallisuus, ongelmanratkaisu, oppiminen, työn merkitys, mahdollisuus auttaa, toimia asiakkaiden parissa jne.) (Arthur ym. 2005; Baruch 2003; Heslin 2005.)

Vastuun urakehityksestä katsotaan siirtyneen työnantajalta työntekijälle. Kuipersin ja Scheeren$\sin (2006)$ mukaan perinteinen ura, joka määrittyi työntekijän hankkiman koulutuksen ja työnantajan häneen tekemien investointien kautta, on muuttunut moderniksi uraksi, joka vetoaa omaehtoisesti hallittuun urakehitykseen. Tähän liittyy se, että urat kehittyvät niin vertikaalisessa kuin horisontaalisessa suunnassa ja urakehitys tapahtuu organisaatiorajojen ulkopuolella, työtehtävät vaihtuvat useammin ja työnantaja ei niinkään tarjoa uratikapuita vakioituine ura-askelmineen vaan luo työntekijöille pikemminkin mahdollisuuksia kehittää omaa uraansa. (Emt.) 
Baruch (2003) kuvaa muutosta seuraavasti:

\begin{tabular}{|c|c|c|}
\hline Aspekti & Perinteinen & Muuttunut \\
\hline Ympäristön luonne & vakaus & liikkuvuus \\
\hline Uraratkaisujen teko & kerran työuran alkuvaiheessa & toistuva, joskus \\
\hline Uravastuu on & organisaatiolla & monilla organisaatioilla \\
\hline Urahorisontti (työpaikka) & yksi organisaatio & useita organisaatioita \\
\hline Urahorisontti (aika) & pitkä & lyhyt \\
\hline Muutoksen ala & vähittäisiä pieniä muutoksia & mullistuksia \\
\hline $\begin{array}{l}\text { Työnantaja odottaa/ } \\
\text { työntekijä tarjoaa }\end{array}$ & lojaalisuus ja sitoutuminen & pitkät työpäivät \\
\hline $\begin{array}{l}\text { Työnantaja tarjoaa/ } \\
\text { työntekijä odottaa }\end{array}$ & työpaikka & investoinnit työllistävyyteen \\
\hline Edistymisen kriteerit & eteneminen virkaiän perusteella & $\begin{array}{l}\text { eteneminen tulosten ja tietämyksen } \\
\text { perusteella }\end{array}$ \\
\hline Menestys tarkoittaa & eteneminen uratikapuilla & sisäinen kokemus saavuttamisesta \\
\hline Koulutus & $\begin{array}{l}\text { muodolliset ohjelmat, } \\
\text { generalistisuus }\end{array}$ & työssä oppiminen, yritysspesifi \\
\hline Urakehityksen ydin & lineaarinen & monisuuntainen \\
\hline
\end{tabular}

Työelämänmittaiseksi tarkoitetun avioliiton kaltaisen suhteen työnantajan ja työntekijän välillä, jossa ero stigmatisoi ja tuotti henkistä kärsimystä, korvaa Baruchin (2003) mielestä ehdollinen kiintymyssuhde, jolle on ominaista toistaisuus, laskelmointi ja joustavuus. Hänen mielestään organisaatioiden tulisi luopua kontrollista ja investoida ihmisiin ja tarjota heille tukea. Henkilöstön hallinnoinnista (personnel management) tulisi siirtyä ihmisten hallinnointiin (people management). (Emt.)

\section{Urasuvantojen välttäminen ja urakehityksen hallinta}

Organisaatioiden kasvu on luonut uramahdollisuuksia viimeiset neljäkymmentä vuotta. Kovan työn ja lahjakkuuden on voinut perustellusti uskoa johtavan ylentämiseen ja jatkuvaan urakehitykseen, vastuun kasvuun työssä, korkeampaan statukseen ja parempaan palkkaan. Nousujohteisen urakehityksen malli on luonut omanlaisensa syndrooman urasuvannoitumisena (career pla- teau). Liikkuvuustietoisessa yhteiskunnassa, jossa urakehityksen ainoaksi suunnaksi on ymmärretty yleneminen, ylentämättä jääminen on tarkoittanut usein odotuksissa pettymistä ja kokemusta henkilökohtaisesta epäonnistumisesta. Joillekin uraputkesta irrottautuminen on merkinnyt henkilökohtaista irrottautumista uraturnajaisista (Slocum ym. 1987). Tällainen luopuminen yleensä kyseenalaistaa sen, mitä ja missä määrin urakehityksen eteen kannattaa uhrata. Raivola ja Raivola (1988, 27) vertaavatkin virassa ylentämistä Cup-kilpailuun, jossa yhden esteen ylittäminen tarkoittaa vain oikeutta osallistua seuraavan, voittamisen kannalta edellistä vaikeampaan kilpaan. Tuloksena on jännite henkilökohtaisen urakehityksen ja yhteistyösuhteiden ylläpitämisen välillä. (Emt.)

Mitä matalammiksi työorganisaatiot ovat tulleet, sitä matalampia ja kapeampia ovat myös niiden tarjoamat vertikaaliset uratikapuut. Mitä enemmän on ylennyksen tavoittelijoita, sitä harvemman osaksi se lankeaa. Urakehitys ajautuu suvantoon yhä useamman kohdalla yhä aikaisemmin ja suvantovaiheista tulee aikaisempaa pidempiä. Perinteinen urakehitys katkeaa enemmin tai myöhem- 
min - nyttemmin yhä ennemmin. (Slocum ym. 1987.)

Urakehityksen tyssääminen on synnyttänyt tutkimusta suvannoitumisen seurauksista. Seurauksia koskevat havainnot ovat osoittautuneet ristiriitaisiksi. Suvantovaihe on myös nähty hyväksi henkilölle itselleen ja omassa kehityksessä tarpeelliseksi osaksi (esim. Choy \& Savery 1996). Negatiiviset seuraamukset syntyvät Feldmanin ja Weitzin $(1988,70)$ mukaan siitä, että henkilö ei kykene todentamaan suorituspotentiaaliaan täysimääräisesti. Kun toimintaympäristö ei muutu, pysyy myös suvantoon ajautunut paikoillaan.

Urakehitys voi päätyä suvantoon henkilökohtaisista syistä tai siksi, ettei sopivia paikkoja vapaudu. Jokaisen kohdalla oma ura-ankkuri ei välttämättä ole toisiin vaikuttamisessa tai toisten valvonnassa, jatkuvassa kriisien voittamisessa ja vallankäytössä, vaan esimerkiksi autonomiassa, omassa työssä pätevöitymisessä tuon työn itsensä, ei jonkin ylemmän tehtävän kannalta, turvallisuudessa, elämäntavan ja tulovirran jatkuvuudessa. Feldmanin ja Weitzin (1988) tarkastelua taustoittaakin ajatus, että työn tekemisen peruspiirre on pyrkimys jatkuvasti ylittää oman suoritustaso - jatkuva parantaminen. He väittävät, että "ei enemmän työtä ellei lisää palkkaa"-asenne johtaa usein urasuvantoon. Heidän mukaansa työntekijät, jotka kykenisivät parempaa, mutta jotka eivät näe parempaan pyrkimistä vaivan väärtiksi johtuen palkkausjärjestelmästä ja löytävät sitten itsensä urasuvannosta, ovat potentiaalisesti kaikkein vahingollisimpia organisaation moraalin ja toiminnan kannalta. (Feldman \& Weitz 1988.)

Ettington $(1997,223)$ erottaa urasuvannoitumisen kielteisinä vaikutuksina ylenemisen tuomien etujen ja palkkioiden menetyksen sekä omaa arvoa koskevien käsitysten laskun. Näiden lisäksi hän puhuu psykologisista, sosiologisista ja organisatorisista vaikutuksista. Ensinnä mainittuja ovat mm. motivaation ja työtyytyväisyyden aleneminen, kun kovan työn positiiviset tulokset jäävät todentumatta ja sen kustannukset tulevat aikaisempaa kirkkaammiksi. Jälkimmäisiin liittyy mm. negatiivinen tyypittely, josta seuraa välttely työtovereiden ja esimiesten taholta, tärkeiden tehtävien ja kehittämisinvestointien suuntautuminen toisille. Nämä näkyvät tuottavuuden laskuna. (Emt.) Urasuvantoon ajautuneen työnarkomaanin ratkaisu on Slocum ym. (1987) mukaan lisätä työhön käytettyä aikaa ja työponnisteluja; tällainen henkilö ei tiedä mitä muutakaan hän voisi tehdä.
Elsass ja Ralston (1989) jäsentävät urasuvannoitumisen käsittelytapoja ja erottavat siinä positiiviset ja negatiiviset reaktiot. Positiivinen käsittely tarkoittaa roolien laajentamista uusien taitojen oppimisena, horisontaalisina siirtyminä tai hankkeisiin osallistumisena, nuorempien työntekijöiden mentorointina ja uudenlaisena, aikaisempaa sisällöllisempänä asennoitumisena omaan työhön. Negatiiviseksi he lukevat organisaatioin vaihtamisen tai sen syyllistämisen, työstä vieraantumisen tai siitä vetäytymisen sekä vihamielisyyden. Oma käsitys urakehityksestä ja siihen liittyvät odotukset välittävät Elsassin ja Ralstonin mielestä urasuvannoitumisen vaikutuksia. Kun uraodotukset ovat korkeat, henkilö todennäköisesti pyrkii laajentamaan taitojaan parantaakseen mahdollisuuksiaan edetä tai hän jättää organisaation. Jos henkilö ei näe uralla etenemistä samassa määrin merkitykselliseksi, ei uran suvannoitumista välttämättä koeta stressaavaksi. Tilannetta on tällöin helpompi käsitellä positiivisesti, esimerkiksi määritellä se uudelleen. Käsittelytavan valintaan vaikuttaa se, miten organisaatio tukee suvannoituneen henkilön käsitystä itsestään ja millaisia muita uraratkaisuja organisaatiolla on tarjota. Elsass ja Ralston olettavat, että sitoutuneet henkilöt ovat taipuvaisia valitsemaan positiivisia käsittelytapoja ja sitoutumattomat negatiivisia. (Emt.)

Appelbaum ja Finestone (1994) pitävät ratkaisevana sitä, miten urasuvannossa oleva näkee kasvamisen ja oppimisen. Kasvaminen ei edellytä ylentämistä vaan viittaa uusien taitojen, asenteiden ja kykyjen kehittämiseen ja hyödyntämiseen. He erottavat kaksitoista eri keinoa, joita ovat mm. horisontaalisten siirtymien mahdollistaminen, jolla torjutaan sisällöllinen suvannoituminen kyllästymisenä, rutinoitumisena ja oppimisen loppumisena, hitaan urakehityksen legitimointi ja edistäminen, jolloin huomio suuntautuu vahvemmin nykyiseen työhön, sen hallintaan ja taitojen kasvattamiseen siinä, työn laajentaminen tai rikastaminen, hankkeet ja mentorointi, taitopohjaiset urapolut, sijaisuudet ja töiden vaihtosysteemit sekä suorituspohjainen palkkaus.

Matalammat, vähemmän ylenemismahdollisuuksia tarjoavat organisaatiot tarvitsevat uudenlaisia motivointikeinoja. Choyn ja Savery (1996) nostavat esiin koetun menestyksen omassa työssä. He havaitsivat, että urasuvannossa olevat pitävät itseään taidoiltaan riittämättöminä korkeampiin tehtäviin ja kokevat joutuvansa tavoittelemaan sellaista oman organisaationsa ulkopuolelta. He toi- 
saalta ilmaisivat enemmän aikomusta vaihtaa organisaatiota ja toisaalta enemmän halua jatkaa työtovereidensa parissa kuin tarttua ylennykseen. Urallaan etenevät puolestaan kokivat uusien työntekijöiden perehdyttämisen palkitsevammaksi ja näkivät omat ja organisaation arvot enemmän yhteneviksi kuin suvantoon ajautuneet (vrt. Ellington 1997). (Choy \& Savery 1996.)

Aikaisempaa matalammissa organisaatioissa ura on nähtävä enemmän horisontaalisena mahdollisuutena luoda ja kehittää pätevyyttä, selvittää haasteita ja myötävaikuttaa tavoitteiden saavuttamiseen (Ellington 1997). Tremblay ja Roger (2004) katsovat tutkimustulosten osoittavan, että työn muotoilu (job design), rikastaminen tai laajentaminen, voi olla tehokas vaikutuskeino johtavassa asemassa olevien, mutta urasuvantoon päätyneiden kohdalla. Seuraamukset ovat negatiivisia erityisesti silloin, kun tehtävät ovat rajoiltaan epäselviä. Tästä syystä keskeistä on selkeyttää odotuksia ja antaa palautetta työssä suoriutumisesta sekä tarjota mahdollisuuksia osallistua päätöksentekoon. Johdon tulisikin tehdä ilmiötä itsessään tunnetuksi (kuuluu kuvioon), pyrkiä pitämään työhön liittyvä sisällöllinen oppiminen jatkuvassa liikkeessä (sisällöllisen suvannoitumisen torjunta, esimerkiksi horisontaaliset siirrot), painottaa vastuun kasvua itsessään ilman hierarkkista kohoamista ja pyrkiä rehelliseen palautteenantoon (Slocum ym. 1987.) Oman osaamisen jatkuva kehittäminen edellyttää välineitä, jotka auttavat omien vahvuuksien ja heikkouksien hahmottamisessa ja tukevat taitojen ja valmiuksien edelleen kehittämistä (Lemire ym. 1999). Allen ym. (1999) korostavat tietoisuuden lisäämistä siitä, että juuri oppimis- ja kehitysorientaatio voi auttaa välttämään urasuvannot jatkuvan omassa työssä kehittymisen kautta.

\section{Horisontaalinen urakehitys - vanhaa viiniä uudessa leilissä?}

Horisontaalisen urakehityksen ideaan, toisin kuin hierarkkiseen uramalliin, ei sisälly mitään maallisen tuolle puolelle yltävää, sen yläpuolelle kohottavaa ja ylennettyä sisäisesti jalostavaa. Se näyttäytyy lähinnä välttämättömyydeltä ja jatkuvalta työltä, joka saattaa estää manalaan suistumisen, mutta joka ei itsessään juuri ylevöitä. Horisontaalisen urakehityksen ajatus käsittää pikemminkin monta pinnanalaista miinaa kuin valmiin ratkaisun nykymuotoisen työelämän haasteisiin.
Yhdellä tasolla ajatus horisontaalisesta urakehityksestä korvaa vertikaalisen urakehityksen selektiivisyyden kaikkien yhdenvertaisuudella - jokainen voi edetä omassa tehtävässään, mutta vain harva organisaatiohierarkiassa. Jos mielikuva kohoamisesta syntyi perinteisessä urakehitysmallissa aina kiitos niiden, jotka jäivät alemmalle tasolle, niin edistymisen osoittimia horisontaalisen urakehityksen kohdalla on etsittävä etäisyydestä omaan aikaisempaan suoriutumiseensa tai läheisyydestä ideaalina olevaan. Tämä tekee edistymisestä häilyvää, hankalaa hahmottaa ja epäselvää kaikissa suhteissa.

Horisontaalisen etenemisen voi nähdä ratkaisuna tilanteeseen, jossa mielenkiinto työhön ja sen sisältöön on haihtunut ja työ on muuttumassa rasittavaksi rutiiniksi, josta ei enää löydy omakohtaista haastetta, uutta opittavaa ja jossa menestys on pikemminkin jotakin, joka luonnehtii omaa työhistoriaa, kuin jotakin, joka vielä siintäisi edessä. Leipääntymisen ongelmaa ei kuitenkaan ratkaista horisontaalisen etenemisen ohjelmilla.

Puhuminen horisontaalisesta etenemisestä korostaa etenemisen merkitystä yleensä. Se voi tarkoittaa sitä, että kaikki ylöspäin suuntautuva eteneminen tapahtuu aina horisontaalisen etenemisen kautta. Aluksi perehdytään laajasti erilaisiin tehtäviin ja vastuisiin, jotka organisaatiohierarkiassa sijoittuvat samalle tasolle, ja vasta tämän jälkeen ylentäminen vaativampiin tehtäviin voi tulla ajankohtaiseksi. Jos ylentämisen odotusajasta on tullut aikaisempaa pidempi ja odottajista aikaisempaa kärsimättömämpiä, on horisontaalisen urakehityksen malli yksi keino pitää heidän huomionsa omassa organisaatiossa ja sen tarjoamissa tehtävissä vielä senkin jälkeen, kun edullisinta olisi ollut jo vaihtaa muualle. Horisontaalinen eteneminen, joka on esivaihe kaikille ennen joidenkin ylentämistä, tarkoittaa, että se on loppujen lopuksi umpikuja useimmille. Siitä ehkä olisi ylläpitämään ylenemisen toivoa pidempään, mutta myös tekemään ylenemättömyydestä, silloin kun se osuisi henkilön omalle kohdalle, aikaisempaa vaikeammin kohdattavan ja käsiteltävän.

Horisontaalisessa urakehityksessä voi nähdä myös lohdutuspalkinnon niille, jotka olisivat ansainneet ylennykset, mutta jotka jäivät ylentämättä paikkojen niukkuudesta johtuen. Horisontaalisuus voi myös tarkoittaa henkilön potentiaalin tunnustamisesta, mutta osoittaa sen samalla laadultaan muuksi kuin sellaiseksi, mitä ylentämiseen vaadittaisiin. Horisontaalisen etenemisen toimimi- 
nen tässä merkityksessä tarkoittaisi, että sen ei pitäisi tulla automaattisesti jokaisen osaksi.

Horisontaalinen urakehityksen idean voi tulkita tarkoittavan aikaisempaa pidemmälle vietyä erikoistamista. Urakehitys olisi näin ollen yhtä kuin mahdollisuus erikoistua. Täten se vaatisi aikaisempaa erikoistuneempaa työnjakoa ja statuserojen luomista tai virallistamista. Näin saataisiin aikaan liikkumismahdollisuuksia, mutta säilytettäisiin organisatorinen asema ennallaan. Hinta vain on usein siinä, että valtaosa joutuu erikoistumaan johonkin "yleiseen". "Yleisen" sisällä hierarkkisuuden periaate rakentuisi sitten esimerkiksi senioriteetin, iän, sukupuolen, kokeneisuuden tms. pohjalta.

Erikoistumisen tarjoamiin mahdollisuuksiin on epäilemättä usein taloudellista tarttua, mutta sitä ei pidä samastaa horisontaaliseksi etenemiseksi. Erikoistuminen luo aina koordinoivan työn tarvetta ja tuo siten kustannuksia. Erikoistuneen tehtävän synty määrittelee aina uudelleen muita tehtäviä ja niiden luonnetta. Organisaatiokaavioihin ilmestyvät uudet, uusia tehtäviä kuvaavat laatikot harvemmin lisäävät laatua, usein juuri päinvastoin. Vaikka yhä useampia tarvitaan kantamaan vastuuta kokonaisuudesta, huomio sektoroituu ja kohdistuu lähinnä seuraamuksiin, ei varsinaisiin ongelmiin ja niiden kokonaisvaltaiseen ratkaisemiseen. Erikoistumisen avulla pyritään palvelemaan perustyötä, mutta lopuksi päädytään yleensä siihen, että perustyötä tekevät joutuvat osaltaan palvelemaan erikoistuneita tehtäviä. Usein spesialisti päätyykin koordinoimaan juuri sen työn suorittamista, joka alun perin oli annettu hänelle tehtäväksi. Erikoistuminen ruokkii edelleen erikoistumista. (Braiden 1992.)

Uskonkin, että horisontaalisen urakehityksen viitekohta on etsittävä jostakin organisaatiohierarkioiden ulkopuolelta. Sopivin viitekohta lienee löydettävissä itsenäisestä ammatinharjoittajasta, joka palvelee luovasti ja luo palvelevasti, ei enkeleistä, jotka ripeästä ja ennakoivasti pyrkivät täyttämään Luojansa toiveet ja loistamaan kirkkaammin, jotta pääsisivät mahdollisimman läheltä Häntä.

\section{Lähteet}

Allen, Tammy, Russell, Joyce, Poteet, Mark \& Dobbins, Gregory (1999). Learning and development factors related to perceptions of job content and hierarchical plateauing. Journal of Organizational Behavior 20, 1113-1137.
Appelbaum, Steven \& Finestone, Dvorah. 1994. Revisiting Career Plateauing. Same Old Problems - Avant-garde Solutions. Journal of Management Psychology 9 (5), 12-21.

Arthur, Michael, Khapova, Svetlana \& Wilderom, Celeste. 2005. Career Success in a Boundaryless Career World. Journal of Organizational Behavior 26, 177-202.

Baruch, Yehuda. 2004. Transforming Careers: From Linear to Multidirectional Career Paths. Organizational and Individual Perspectives. Career Development International 9 (1), 5873.

Baruch, Yehuda \& Peirperl, Maury (2000). Career management practices: An empirical survey and implications. Human Resource Management. 39(4), 347-366.

Béteille, André (1979). Homo Hierarchicus, Homo Equalis. Modern Asian Studies 13 (84), 529-548.

Braiden, Chris (1992). Enriching traditional roles. Teoksessa Larry Hoover (toim.) Police management. Issues \& perspectives. Huntsville: Sam Houston State University, 87-116.

Choy, Rita \& Savery, Lawson (1998). Employee Plateauing: Some Workplace Attitudes. Journal of Management Development 17 (6), 392401.

Daniels, Norman (1978). Merit and meritocracy. Philosophy and Public Affairs 7 (3), 206-223.

Davis, Jon (2006). Meritocracy in the Civil Service 1853-1970. Political Quarterly, 27-35.

Dench, Geoff (2006). Introduction: Reviewing meritocracy. The Political Quarterly, 1-14.

Elsass, Priscilla \& Ralston, David (1989). Individual responses to the stress of career plateauing. Journal of Management 15 (1), 35-47.

Ettington, Deborah (1997). How human resource practices can help plateaued managers Succeed. Human Resource Management 36 (2), 221-234.

Feld, M. (1959). Information and authority: the Ssructure of military organization. American Sociological Review 24 (1), 15-22.

Feldman, Daniel \& Weitz, Barton (1988). Career plateaus reconsidered. Journal of Management 14 (1), 69-80.

Fuller, Steve (2006). The new sociological imagination. London: Sage. 
Heslin, Peter (2005). Conceptualizing and evaluating career success. Journal of Organizational Behavior 26, 113-136.

Horowitz, Irving (2006). Comment: the moral economy of meritocracy. Modern age, Summer, 281-286.

Jacobs, David (1981). Toward a theory of mobility and behavior in organizations: an inquiry into the consequences of some relationship between individual performance and organizational success. American journal of Socio$\log 887$ (3), 684-707.

Janowitz, Morris (1959). Changing patterns of organizational authority: the military establishment. Administrative Science Quarterly 3 (4), 473-493.

Kaempffert, Waldemar (1941). War and technology. American Journal of Sociology 46, 431444.

Krauze, Tadeusz \& Slomczynski, Kazimierz (1985). How far to meritocracy? Empirical test of a controversial thesis. Social Forces 63 (3), 623-642.

Leonard, V. \& More, Harry. 2000. Police Organization and Management (9. painos). New York: Foundation Press.

Lister, Ruth (2006). Ladder of opportunity or engine of inequality? Political Quarterly, 232236.

McCoy, Shannon \& Major, Brenda (2007). Priming meritocracy and the psychological justification of Inequality. Journal of Experimental Social Psychology 43, 341-351.

McNulty, Paul (1973). Adam Smith's concept of labour. Journal of History of Ideas 34 (3), 345-366.

Mohamed, Feisal (2004). Renaissance thought on the celestial hierarchy: the decline of a tradition? Journal of the History of Ideas 65 (4), 559-582.

Nisbet, Robert (1979). The idea of progress. Literature of Liberty: A Review of Contemporary Liberal Thought 2 (1). 14-41.

Patrides, C. (1959). Renaissance thought on the celestial hierarchy: the decline of a tradition. Journal of the History of Ideas 20 (2), 155166.

Raivola, Reijo \& Raivola, Petri (1988). Kokelaasta komisarioksi. Poliisiuran kolmetoista ensim- mäistä vuotta. Sisäasiainministeriön poliisiosaston julkaisusarja 2C.

Saunders, Peter (2006). Meritocracy and popular legitimacy. Political Quarterly, 183-194.

Segal, David \& Segal, Mady (1983). Change in military organization. American Review of Sociology 9, 151-170.

Slocum, John (1987). Whose career is likely to plateau. Business Horizons, March-April, 3038.

Strawson, P.F. (1992). Analysis and metaphysics. An introduction to philosophy. Oxford: Oxford University Press.

Tremblay, Michel \& Roger, Alain (2004). Career Plateauing Reactions: The Moderating Role of Job Scope, Role ambiquity and participation among Canadian managers. International Journal of Human Resource Management 15 (6), 996-1017.

Thrupp, Sylvia (1959). Hierarchy, illusion, and social mobility. Comparative Studies in Society and History 2 (1), 126-128.

Willets, David (2006). The future of meritocracy. Political Quarterly, 237-243.

Wren, Daniel (1994). The evolution of management thought. John Wiley \& Sons.

\section{Viite}

1. Sosiaalinen lähtöasema rajoittaa yhä vähemmän korkeampien sosiaalisten asemien tavoittelua koulutuksen kautta. Parempiosaisilla on kuitenkin paremmat mahdollisuudet rajoittaa jälkikasvunsa sosiaalista putoamista. On eri asia lisätä yksilöiden välistä yhdenveroisuutta mahdollisuuksien tasa-arvoon vaikuttamalla kuin rajoittaa joidenkin mahdollisuuksia ostaa lapsilleen opiskelupaikka arvostetuissa opinahjoissa. (Saunders 2006.)

Artikkeli saapui toimitukseen 26.8.2009.

Se hyväksyttin julkaistavaksi toimituskunnan kokouksessa 30.11.2009. 